\title{
The seasonality in the diagnosis of acute leukemia: A single center data from Turkey
}

\author{
Akut lösemi tanısında mevsimsel dağılım: Türkiye'den tek merkez verisi \\ Rafet EREN, Mehmet Hilmi DOĞU, Şermin ALTINDAL, Osman YOKUŞ, Elif SUYANI
}

\begin{abstract}
Objectives: The seasonality in the diagnosis of acute leukemias (ALs) has been conceived ever since and the results have been confounding between summer and winter peaks since those times. To our knowledge, the seasonality in the diagnosis ALs has not been explored in our region and we aimed to investigate for a seasonal accumulation in the diagnosis of AL patients.

Materials and Methods: A hundred and sixty-two patients who were diagnosed with either acute myeloid leukemia (AML) or acute lymphocytic leukemia (ALL) between November 2012 and October 2017 were included in the study. The data regarding the gender, age, type of leukemia and the time of admission were noted from files of the patients.

Results: The median age of the patients was 51.5 years (range, 17-85) with 64 (39.5\%) female, 98 (60.5\%) male. Most of AL patients were diagnosed in August $(21,13 \%)$ and the least in June with $6(3.7 \%)$ patients. According to the seasons; 39 (24.1\%) patients were diagnosed in winter, $40(24.7 \%)$ patients in spring, $40(24.7 \%)$ patients in summer and $43(26.5 \%)$ patients in autumn $(\mathrm{P}>0.05)$.

Conclusion: We could not determine any seasonality in the diagnosis of ALs, both AML and ALL, in our study.
\end{abstract}

Keywords: Acute myeloid leukemia, Acute lymphoblastic leukemia, Seasonality

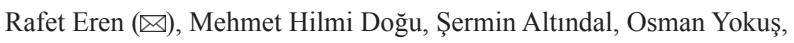
Elif Suyanı

Department of Hematology, Istanbul Training and Research Hospital, University of Health Sciences, Istanbul, Turkey

e-mail:drrafeteren@gmail.com

Submitted / Gönderilme: 17.07.2018

Accepted/Kabul: 11.09.2018
ÖZ

Amaç: Akut lösemilerin (AL) tanısında mevsimsel değişkenlik olabileceği uzun süredir düşünülüyor olsa da yapılan çalışmaların sonuçları yaz ve kış pikleri arasında çelişkilidir. Bilindiği kadarıyla bölgemizde AL tanısında mevsimsel değişkenlik incelenmemiştir. Bu çalışmada AL hastalarının tanısında mevsimsel bir birikim olup olmadığını araştırmayı amaçladık.

Yöntemler ve Gereçler: Kasım 2012 ile Ekim 2017 tarihleri arasında akut myeloid lösemi (AML) veya akut lenfositik lösemi (ALL) tanısı alan 162 hasta çalışmaya dâhil edildi. Cinsiyet, yaş, lösemi tipi ve hastaneye yatış bilgileri hasta dosyalarından edinildi.

Bulgular: Hastaların medyan yaş1 51,5 idi (aralık: 17-85). 64 hasta $(\% 39,5)$ kadın, 98 'i ise $(\% 60,5)$ erkekti. AL tanıs1 alan 21 hasta (\%13) ile en sık Ağustos ayında iken, 6 hasta $(\% 3,7)$ ile en nadir Haziran ayındaydı. Mevsimlere göre incelendiğinde, 39 hasta $(\% 24,1)$ kış, 40 hasta $(\% 24,7)$ ilkbahar, 40 hasta $(\% 24,7)$ yaz ve 43 hasta $(\% 26,5)$ ise sonbahar mevsiminde tanı almıştı $(\mathrm{P}>0,05)$.

Sonuç: Hem AML hem de ALL açısından bakıldığında, çalışmamızda AL tanısında herhangi bir mevsimsel değişkenlik belirleyemedik.

Anahtar kelimeler: Akut myeloid lösemi, Akut lenfoblastik lösemi,Mevsimsel dağılım

\section{Introduction}

Acute leukemias (ALs) are the hematological malignancies characterized by abnormal proliferation of blasts derived from either a hematopoietic myeloid precursor or a hematopoietic lymphoid precursor or both. While, the most common type of $\mathrm{AL}$ in adults is the acute myeloid leukemia (AML) with an incidence of 5-8/100.000 [1,2], acute lymphoblastic leukemia (ALL) is encountered less frequently with an incidence of 1.28/100000 [3]. Although, ALs are rarely seen, they remain to have an acute onset and a clinical course with high morbidity and mortality rates in adults, despite the significant improvements in treatment modalities [1-3]. The acute onset nature of ALs has raised 
the question whether the diagnosis of ALs shows a seasonal variation or not. Hence, the seasonality in the diagnosis of ALs has been conceived ever since [4-8] and the results have been confounding between summer and winter peaks since that time [9-14].

To our knowledge, the seasonality in the diagnosis ALs has not been explored in our region. In this study, we aimed to investigate whether there is a seasonal accumulation in the diagnosis of $\mathrm{AL}$ and if there is, its possible causes including sunshine exposure and infection epidemics.

\section{Materials and Methods}

A hundred and sixty-two patients diagnosed with either AML or ALL (except secondary AML, acute promyelocytic leukemia or ALL with type 3 blast) between November 2012 and October 2017 at Marmara University Hospital Hematology Department were included in the study. The data regarding the gender, age, type of leukemia and the time of admission were noted from files of the patients.

\section{Statistical Analysis}

Statistical evaluation was made by SPSS 22 program. Data were described as numbers and percentage or median and range, when appropriate. $\mathrm{x}^{2}$ Fisher's exact test was used for evaluating categorical values. All P-values were 2-sided with statistical significance at 0.05 alpha levels.

\section{Results}

The median age of the patients was 51.5 years (range 17$85)$ with 64 (39.5\%) female, $98(60.5 \%)$ male. The subtype of $110(67.9 \%)$ patients were AML and $52(32.1 \%)$ were ALL (Table I). The distribution of the leukemias according to the months is presented in Figure 1. When the patients were evaluated separately as AML and ALL, no seasonal accumulation was observed (Table II). The diagnosis of AL was most frequent in August with $21 / 13 \%$ ) patients and least in June with $6(3.7 \%)$ patients. According to the seasons; 39 (24.1\%) patients were diagnosed in winter, $40(24.7 \%)$ patients in spring, $40(24.7 \%)$ patients in summer and $43(26.5 \%)$ patients in autumn $(\mathrm{P}>0.05)$. The distribution was similar when subgroup analysis were done based on gender and leukemia subtype.
Table I. Patient characteristics

\begin{tabular}{|l|l|}
\hline & $\mathrm{N}=162$ \\
\hline Gender, n, (\%) & \\
Female & $64(39.5 \%)$ \\
Male & $98(60.5 \%)$ \\
\hline Age, years, median, (range) & $51.5(17-85)$ \\
\hline Leukemia subtype, n, (\%) & \\
AML & $110(67.9 \%)$ \\
ALL & $52(32.1 \%)$ \\
\hline
\end{tabular}

ALL: acute lymphocytic leukemia; AML: acute myeloid leukemia

Table II. Distribution of months of diagnosis in patients with AML and ALL

\begin{tabular}{llccccc} 
& & \multicolumn{3}{c}{ AML } & & ALL \\
\cline { 3 - 4 } \cline { 6 - 7 } & & $\mathrm{n} \%$ & & & $\mathrm{n} \%$ \\
\hline \multirow{7}{*}{ Months of } & January & 11 & $10.0 \%$ & & 4 & $7.7 \%$ \\
& February & 7 & $6.4 \%$ & & 4 & $7.7 \%$ \\
& March & 12 & $10.9 \%$ & & 5 & $9.6 \%$ \\
& April & 3 & $2.7 \%$ & & 9 & $17.3 \%$ \\
& May & 9 & $8.2 \%$ & & 3 & $3.8 \%$ \\
& June & 3 & $2.7 \%$ & & 3 & $5.8 \%$ \\
& July & 6 & $5.5 \%$ & & 7 & $13.5 \%$ \\
& August & 16 & $14.5 \%$ & & 5 & $9.6 \%$ \\
& September & 10 & $9.1 \%$ & & 4 & $7.7 \%$ \\
& October & 10 & $9.1 \%$ & & 3 & $5.8 \%$ \\
& November & 14 & $12.7 \%$ & & 2 & $3.8 \%$ \\
& December & 9 & $8.2 \%$ & & 4 & $7.7 \%$ \\
\hline
\end{tabular}

ALL: acute lymphocytic leukemia; AML: acute myeloid leukemias

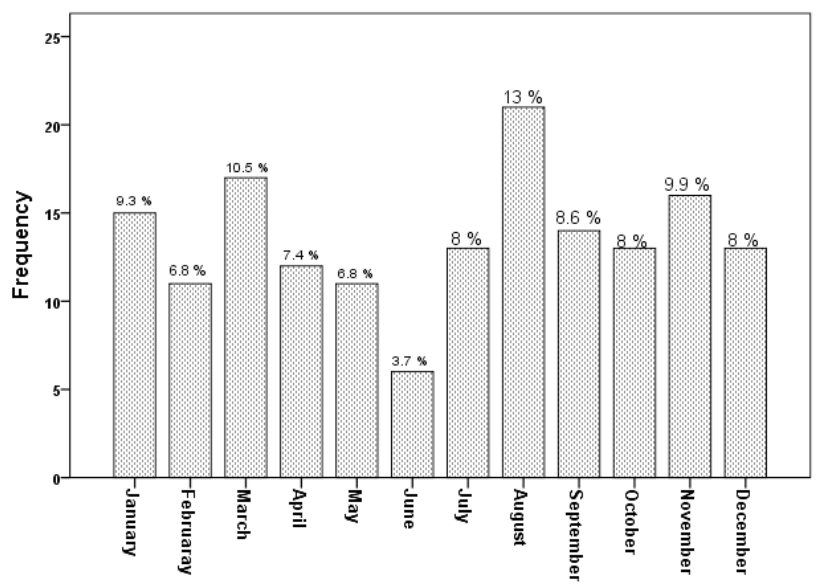

Figure 1. Distribution of the diagnosis of leukemias according to the months

\section{Discussion}

The pathogenesis of ALs comprises complex sequence of events including chromosomal translocations and/ 
or inversions and/or point mutations, all of which alter the proliferation and differentiation of the hematopoietic precursor cells [1-3]. The triggering factor, which initiates those events, has not been elucidated so far. It has been suspected that viruses could be one of the potential triggering factors linked to ALs. The role of JC virus, Ebstein-Barr virus, cytomegalovirus, human herpes virus 6 and 7, and parvo virus B19 has been investigated as an etiologic factor in AL and among them parvo virus B19 was found to be potentially involved in the etiology of AL [15-19]. Actually, the data regarding the role of viruses, especially the ones causing respiratory infections which are mostly encountered in winter, is obscure in occurrence of ALs. Hereby, seasonality of ALs has been an intriguing topic thus we also investigated it in our clinics. However, we could not demonstrate a seasonal variation in the diagnosis of ALs. Similarly, subgroup analysis according to subtype of AL and gender did not show any seasonal variation in the diagnosis of ALs. When the patients were evaluated in general, the least common month of diagnosis was June. This could be due to the population of Istanbul moving temporarily to other cities for vocational purposes.

The seasonality in diagnosis of ALs particularly ALL has been investigated with studies including quite enough number of patients [9-14, 20]. Gao et al., investigated variation in the seasonal diagnosis of ALL in 3 different regions of the World, which allowed a more accurate evaluation, because the selected regions were located located on different altitudes and had entirely different climates [9]. While there was no seasonal peak in the diagnosis of ALL in Singapore and the United States, a winter peak was observed in Sweden where seasons differ prominently unlike the climate of other selected regions. Similarly Timomen et al., also found a winter peak in the diagnosis of ALL patients in a study from Finland [10]. Furthermore, they investigated the association between the peak and influenza epidemic, which has been the basis for the seasonality postulate in the diagnosis of ALs. And they demonstrated that more ALL were diagnosed during influenzae epidemics. On the other hand, their analysis did not reveal those findings for AML. Another considerable point is that, due to the presence of winter peak in the diagnosis of ALL in the North areas of the World, they hypothesized that vitamin D deficiency might be associated with the initiation of the disease because of the sunlight deprivation in winter. Eatough et al., studied the seasonality in the diagnosis of acute monocytic leukemia in England which is also located in the North part of the World, and determined a peak in February and March [11]. In terms of AML, Calip et al., found a winter peak in the diagnosis of AML in a quite high number of patients in different regions of the United States [12]. In contrast to former studies, Badrinath et al., demonstrated a summer peak in the diagnosis of ALL in England [13]. Ross et al., also demonstrated a summer peak in the diagnosis of ALL in the United States with a high number of patients [14]. Gao et al., showed that there was not a prominent seasonal variation in the diagnosis of ALL in a meta-analysis [20]. But, the meta-analysis was quite heterogeneous regarding the age of the patients. After all these conflicting results we could not determine any seasonality in the diagnosis of ALs, both AML and ALL, in Turkey.

Although limited number of patients and patients being from a single center seem to be the limitations of this study, our hospital is located in Istanbul which is the most crowded city of Turkey and has received a major of influx from nearly all parts of Turkey. So, our study population can be the representative of Turkey. In fact the most significant limitation of this study similar to the other ones, is the lack of antecedent infection history of the patients.

In conclusion, given the complexity of the pathogenesis of AL, achievement of a precise conclusion about the seasonality in the diagnosis of ALs could not be feasible despite the studies including large number of patients.

\section{Conflict of Interest}

The authors declare that they have no conflict of interest

\section{Funding}

There is no funding source

\section{References}

1. Fey MF, Buske C. ESMO Guidelines Working Group. Acute myeloblastic leukaemias in adult patients: ESMO Clinical Practice Guidelines for diagnosis, treatment and follow-up. Ann Oncol 2013;24 Suppl 6:vi138-43. doi: 10.1093/annonc/ mdt320. Epub 2013 Aug 22.

2. De Kouchkovsky I, Abdul-Hay M. Acute myeloid leukemia: a comprehensive review and 2016 update. Blood Cancer J 2016 Jul 1;6:e441. doi: 10.1038/bcj.2016.50.

3. Hoelzer D, Bassan R, Dombret H, Fielding A, Ribera JM, Buske C. ESMO Guidelines Committee. Acute lymphoblastic leukaemia in adult patients: ESMO Clinical Practice Guidelines for diagnosis, treatment and follow-up. Ann Oncol 2016;27 Suppl 5:v69-v82. doi:10.1093/annonc/ mdw025 Epub 2016 Apr 7. 
4. Hayes DM. The seasonal incidence of acute leukemia. A contribution to the epidemiology of the disease. Cancer 1961;14:1301-5.

5. Lee JA. Seasonal variation in the clinical onset of leukemia in young people. Br Med J 1962;1(5294):1737-8.

6. Lee JA. Seasonal variations in the incidence of the clinical onset of leukemia. Pathol Microbiol (Basel). 1964;27:772-6.

7. Allan TM.Seasonal onset of acute leukemia. Br Med J 1964;2(5409):630.

8. Gunz FW, Spears GF. Distribution of acute leukaemia in time and space. Studies in New Zealand. Br Med J 1968;4(5631):604-8.

9. Gao F, Nordin P, Krantz I, Chia KS, Machin D. Variation in the seasonal diagnosis of acute lymphoblastic leukemia: evidence from Singapore, the United States, and Sweden. Am J Epidemiol 2005;162:753-63. doi: 10.1093/aje/kwi272 Epub 2005 Aug 31.

10. Timonen TT. A hypothesis concerning deficiency of sunlight, cold temperature, and influenza epidemics associated with the onset of acute lymphoblastic leukemia in northern Finland. Ann Hematol 1999;78:408-14.

11. Eatough JP. Evidence of seasonality in the diagnosis of monocytic leukaemia. Br J Cancer 2002;87:509-10. doi: 10.1038/sj.bjc.6600497

12. Calip GS, McDougall JA, Wheldon MC, Li CI, De Roos AJ. Evaluation of seasonality in the diagnosis of acute myeloid leukaemia among adults in the United States, 1992-2008. Br J Haematol 2013;160:343-50. doi: 10.1111/bjh.12137. Epub 2012 Nov 28.
13. Badrinath P, Day NE, Stockton D. Seasonality in the diagnosis of acute lymphocytic leukaemia. Br J Cancer 1997;75:1711-3

14. Ross JA, Severson RK, Swensen AR, Pollock BH, Gurney JG, Robison LL. Seasonal variations in the diagnosis of childhood cancer in the United States. Br J Cancer 1999 Oct;81(3):549-53. doi: 10.1038/sj.bjc.6690729r

15. Richardson RB. Promotional etiology for common childhood acute lymphoblastic leukemia: the infective lymphoid recovery hypothesis. Leuk Res 2011;35:1425-31. doi:10.1016/j.leukres.2011.07.023.

16. Smith M. Considerations on a possible viral etiology for B-precursor acute lymphoblastic leukemia of childhood. J Immunother 1997;20:89-100.

17. Morales-Sánchez A, Pompa-Mera EN, Fajardo-Gutiérrez A, et al. EBV, HCMV, HHV6, and HHV7 screening in bone marrow samples from children with acute lymphoblastic leukemia. Biomed Res Int 2014;2014:548097. doi: $10.1155 / 2014 / 548097$.

18. Kerr JR, Mattey DL. The role of parvovirus B19 and the immune response in the pathogenesis of acute leukemia. Rev Med Virol 2015;25:133-55. doi: 10.1002/rmv.1830.

19. Deschler B, Lübbert M. Acute myeloid leukemia: epidemiology and etiology. Cancer 2006;107:2099-107. doi:10.1002/cncr.22233

20. Gao F, Chia KS, Machin D. On the evidence for seasonal variation in the onset of acute lymphoblastic leukemia (ALL). Leuk Res 2007;31:1327-38. doi:10.1016/j. leukres.2007.03.003 